\title{
Diseases and causes of mortality among sea turtles stranded in the Canary Islands, Spain (1998-2001)
}

\author{
J. Orós ${ }^{1, *}$, A. Torrent ${ }^{1}$, P. Calabuig ${ }^{2}$, S. Déniz ${ }^{3}$ \\ ${ }^{1}$ Unit of Histology and Pathology, Veterinary Faculty, University of Las Palmas de Gran Canaria (ULPGC), Trasmontaña s/n, \\ 35416 Arucas, Las Palmas, Spain \\ ${ }^{2}$ Tafira Wildlife Rehabilitation Center, Tafira Baja, 35017 Las Palmas de Gran Canaria, Spain \\ ${ }^{3}$ Unit of Infectious Diseases, Veterinary Faculty, University of Las Palmas de Gran Canaria (ULPGC), Trasmontaña s/n, \\ 35416 Arucas, Las Palmas, Spain
}

\begin{abstract}
This paper lists the pathological findings and causes of mortality of 93 sea turtles (88 Caretta caretta, 3 Chelonia mydas, and 2 Dermochelys coriacea) stranded on the coasts of the Canary Islands between January 1998 and December 2001. Of these, 25 (26.88\%) had died of spontaneous diseases including different types of pneumonia, hepatitis, meningitis, septicemic processes and neoplasm. However, 65 turtles $(69.89 \%)$ had died from lesions associated with human activities such as boat-strike injuries $(23.66 \%)$, entanglement in derelict fishing nets $(24.73 \%)$, ingestion of hooks and monofilament lines (19.35\%), and crude oil ingestion $(2.15 \%)$. Traumatic ulcerative skin lesions were the most common gross lesions, occurring in $39.78 \%$ of turtles examined, and being associated with Aeromonas hydrophila, Vibrio alginolyticus and Staphylococcus spp. infections. Pulmonary edema $(15.05 \%)$, granulomatous pneumonia $(12.90 \%)$ and exudative bronchopneumonia $(7.53 \%)$ were the most frequently detected respiratory lesions. Different histological types of nephritis included chronic interstitial nephritis, granulomatous nephritis and perinephric abscesses, affecting 13 turtles $(13.98 \%)$. Ulcerative and fibrinous esophagitis and traumatic esophageal perforation were the most frequently observed lesions in the esophagus, being associated in the majority of the cases with ingestion of fishing hooks. Larval nematodes of the Anisakidae family caused gastritis in 15 turtles (16.13\%). Necrotizing and/or granulomatous hepatitis were the lesions most commonly observed in the liver $(27.95 \%)$. Traumatic lesions included necrotizing myositis $(10.75 \%)$ mainly caused by entanglement in fishing nets or boat-strikes, and amputation of 1 or 2 flippers (25.81\%) by netting. Traumatic erosions and/or fractures of the carapace/plastron mainly caused by boat-strikes were also observed $(26.88 \%)$. Eye lesions included heterophilic keratoconjunctivitis, ulcerative keratitis and heterophilic scleritis, affecting 7 turtles $(7.53 \%)$.
\end{abstract}

KEY WORDS: Sea turtle $\cdot$ Pathology $\cdot$ Loggerhead turtle $\cdot$ Caretta caretta $\cdot$ Reptile

Resale or republication not permitted without written consent of the publisher

\section{INTRODUCTION}

The efforts to conserve sea turtles, the advances in their medical management, and the studies on causes of mortality of stranded sea turtles have increased in recent years. Currently, 2 families and 7 species of sea turtles are recognized (Pritchard 1997). The family Cheloniidae comprises the green turtle Chelonia mydas, loggerhead Caretta caretta, hawksbill Eretmochelys imbricata, Kemp's ridley Lepidochelys kem- pi, olive ridley L. olivacea and flatback Natator depressus. The family Dermochelyidae comprises only the leatherback Dermochelys coriacea. Only 5 species have been reported from the Canary Islands: loggerhead, green turtle, leatherback, hawksbill and Kemp's ridley (Mateo et al. 1997, Barbadillo et al. 1999).

Sea turtles can be affected by several diseases. Some of these health problems are naturally occurring processes and are observed in both wild and captive turtles. Other conditions, such as certain nutritional defi- 
ciencies, are essentially a result of prolonged captivity in wildlife rehabilitation centers (George 1997).

All species of sea turtles are included in the 'red list' of the World Conservation Union (IUCN/SSC 2002). The IUCN/SSC (1995) has emphasized research on diseases of sea turtles as a priority issue.

There are reports of disease surveys of wild sea turtles in Australia (Glazebrook \& Campbell 1990b, Raidal et al. 1998), Hawaii (Work \& Balazs 1998), France (Duguy et al. 1998) and Florida (Smith \& Coates 1938).

This paper lists the pathological findings and causes of mortality of 93 sea turtles

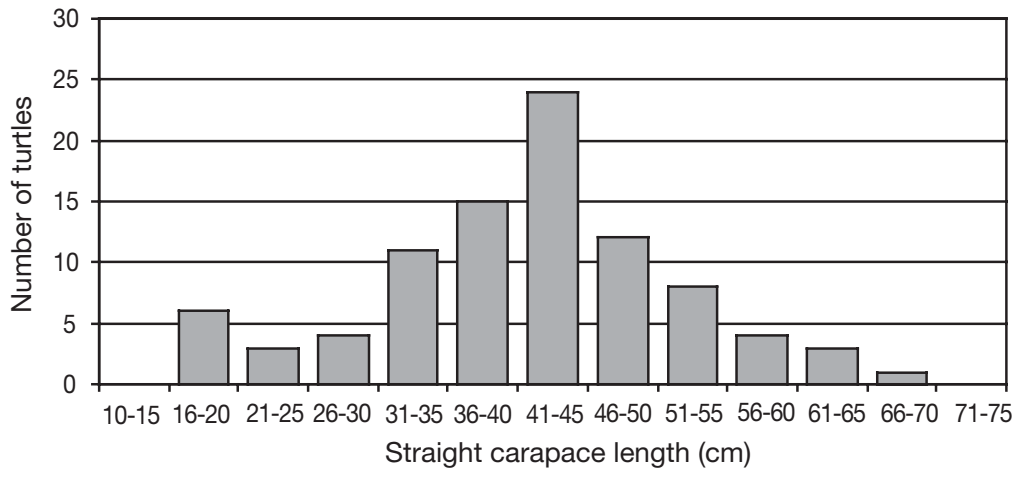

Fig. 1. Caretta caretta and Chelonia mydas. Straight carapace length of loggerhead and green turtles necropsied in this study $(\mathrm{n}=91)$

stranded on the coasts of the Canary Islands between January 1998 and December 2001.

\section{MATERIALS AND METHODS}

Between January 1998 and December 2001, 93 sea turtles that stranded on the coasts of the Canary Islands were submitted for necropsy to the Veterinary Faculty, University of Las Palmas de Gran Canaria (ULPGC). Some of them had been previously submitted to the Tafira Wildlife Rehabilitation Center (TWRC) for health evaluation, medical management and possible rehabilitation.

Species identifications were made according to Frick (1996). Turtles belonging to 3 different species were examined: 88 Caretta caretta (94.62\%), 3 Chelonia mydas (3.23\%), and 2 Dermochelys coriacea $(2.15 \%)$. Of these, 82 turtles were female $(88.17 \%)$ and 11 male $(11.83 \%)$. The total number of stranded turtles from each of the Canarian Islands is listed in Table 1.

On the basis of straight carapace length (SCL) (Fig. 1) and sexual maturity (estimated from the appearance of their gonads), all specimens of Caretta caretta and Chelonia mydas were identified as juvenile or subadult turtles (Chaloupka \& Musick 1997). The 3 specimens of Dermochelys coriacea were adults.

Turtles with a clinical history of fractures of the humerus, ulna, radius or femur, were positioned in

Table 1. Number and percentage of stranded turtles distributed by island

\begin{tabular}{|lrr|}
\hline Island & $\mathrm{n}$ & $\%$ \\
\hline Gran Canaria & 45 & 48.38 \\
Tenerife & 26 & 27.95 \\
Fuerteventura & 14 & 15.05 \\
Lanzarote & 6 & 6.45 \\
La Gomera & 2 & 2.15 \\
\hline
\end{tabular}

ventral recumbency and X-rayed. The images were obtained using Bennet $300 \mathrm{HFQ}$ equipment, with the following parameters: $150 \mathrm{~mA}, 52 \mathrm{kVP}, 6.8 \mathrm{mAs}$.

Pathological study. Necropsies were performed at the Veterinary Faculty, ULPGC. The gross postmortem examinations were carried out using the procedures previously described by Wolke \& George (1981), Campbell (1996), and Orós \& Torrent (2001).

The condition of the turtles ranged from freshly dead to moderately autolyzed. Macroscopic lesions were recorded and tissue samples from all major organs were fixed in $10 \%$ neutral buffered formalin, embedded in paraffin, sectioned at $5 \mu \mathrm{m}$ for light microscopy, and stained with hematoxylin and eosin (H\&E). Special stains used on selected cases included Gram-stain for bacteria, Ziehl Neelsen (ZN) for acid-fast organisms, periodic acid-Schiff (PAS) for protozoa and fungal hyphae, Grocott's methenamine silver nitrate (GMS) for fungi, and von Kossa stain for calcium (Bancroft \& Stevens 1996). Selected samples from the thymus and epicardium of Turtle No. 401/98 were fixed in 2.5\% buffered glutaraldehyde, routinely processed for transmission electron microscopy and embedded in epoxy resin (Wanson \& Drochman 1988). Ultrathin sections were mounted on grids, stained with uranyl acetate and lead citrate and examined with a Zeiss 910 microscope.

Microbiological and mycological studies. Samples were taken from gross lesions and cultured on a variety of selective and non-selective media including blood agar (Oxoid), MacConkey agar (Oxoid), Baird Parker agar (Oxoid) for staphylococci, and Sabouraud dextrose agar (Oxoid) for fungi and yeasts. All cultures were incubated at $25^{\circ} \mathrm{C}$ aerobically. Once a pure growth had been obtained, bacteria were identified based on the biochemical profile (API 20 E, API 20 NE, and API 20 STAPH, BioMérieux).

Parasitological study. A routine search was made for internal parasites by examining the internal organs in situ. Routine examination of the cardiovascular system 
for spirorchids included the cardiac chambers, the left and right pulmonary arteries, the left and right aortas, the brachiocephalic trunk, and the hepatic veins. Inner surfaces were examined and then washed with water to free any flukes still attached (Greiner et al. 1980, Gordon et al. 1998). The alimentary tract was ligated at the level of the esophagus and colon. Helminths were fixed by immersion in $70 \%$ ethanol and glycerine. Fecal specimens were processed as previously described (Boch \& Supperer 1982).

\section{RESULTS}

\section{Systemic diseases}

Table 2 lists the lesions observed in the surveyed sea turtles. Cachexia was diagnosed in 22 turtles $(23.66 \%)$ based on muscle atrophy, sunken eyes and the presence of a concave plastron; 7 turtles $(7.53 \%)$ were moderately autolyzed.

Ulcerative skin lesions attributed to trauma were the most common gross lesions, occurring in $39.78 \%$ of turtles examined. The distribution of the skin lesions was multifocal, with multiple lesions (1 to $4 \mathrm{~cm}$ in diameter), especially on the dorsum of the neck, head and flippers. Skin lesions were characterized by the ulceration of the epidermis, necrosis of the epidermis and dermis with infiltrating degenerative granulocytes and bacteria, and an underlying layer of multinucleated giant cells.

Pulmonary edema was the most frequently observed respiratory lesion (14/93 or $15.05 \%)$. Granulomatous pneumonia (12/93 or $12.90 \%$ ) and exudative bronchopneumonia (7/93 or $7.53 \%$ ) were frequently detected respiratory lesions. Granulomatous pneumonia was characterized by the presence of well defined granulomas (Fig. 2) containing central areas of eosinophilic necrotic debris mixed with heterophils and macrophages. Multinucleated giant cells surrounding the necrotic debris were observed in some granulomas. All granulomas were negative for mycobacteria (ZN) and fungi (GMS, PAS). Exudative bronchopneumonia was characterized by the presence of numerous heterophils in the central lumen of bronchi and bacterial colonies. In the majority of cases the pneumonic lesions were unilateral.

Fibrinous exudative pericarditis was the lesion most commonly observed (4/93 or $4.30 \%$ ) in the cardiovascular system. In 1 of the turtles, this lesion was associated with Staphylococcus xylosus infection. Staphylococcus spp. was isolated from 1 other turtle and no bacteria were isolated from 2 turtles.

Multifocal necrotizing splenitis was the most frequent lesion affecting the spleen (7/93 or $7.53 \%$ ). All cases of multifocal necrotizing splenitis were associated with septicemic processes. Lymphoblastic lymphoma was diagnosed in a juvenile loggerhead, with tumoral white nodules in the thymus, plastron, thyroid gland, heart, aorta, left lung, spleen, liver, kidneys, stomach and small intestine. Nodular, unencapsulated masses or monotonous sheets composed of hyperchromatic neoplastic lymphoid cells were detected in these organs. Transmission electron microscopy revealed a moderately polymorphous population of round and oval cells with central rounded or oval nuclei, peripherally clumped heterochromatin, and 2 or more nucleoli (Orós et al. 2001).

Several lesions were observed in the excretory system. Lesions included chronic interstitial nephritis, granulomatous nephritis (Fig. 3) and perinephric abscesses, affecting 13 turtles (13.98\%) (Table 2). Chronic interstitial nephritis was characterized by the presence of aggregates of lymphocytes in the renal interstitium and was also associated with renal interstitial fibrosis. Granulomatous nephritis was characterized by small, yellow-white, granulomatous foci scattered randomly throughout the kidney. Microscopically, granulomas were characterized by central foci of necrosis surrounded by macrophages and multinucleated giant cells (Fig. 3, inset). Perinephric abscesses implied extension of exudative inflammation through the renal capsule into the perinephric tissue, and were composed of fibrinous exudates containing debris of perished inflammatory cells surrounded by a capsule of connective tissue. Exudative salt-gland adenitis was observed in 2 loggerhead turtles.

Ulcerative and fibrinous esophagitis and traumatic esophageal perforation were the most frequently observed lesions in the esophagus, being associated in the majority of the cases with ingestion of fishing hooks identified as originating from longline tuna fishery. Lesions were characterized by the ulceration of the esophageal mucosa, a coating of eosinophilic fibrillar material consistent with fibrin, with infiltrating degenerate granulocytes and bacteria in the lamina propria and/or submucosa, and an underlying layer of multinucleated giant cells. Esophageal impaction with balls of crude oil was observed in 2 turtles $(2.15 \%)$.

Larval nematodes from the Anisakidae family caused gastritis in 15 turtles (16.13\%). The migration of larvae from the lumen of the stomach to the celomic cavity was characterized by the presence of granulomas in the lamina propria, submucosa (Fig. 4), lamina muscularis and serosa of the stomach and mucosal ulceration. Different histological types of enteritis included catarrhal enteritis, fibrinous enteritis, necrotizing enteritis, and fibrinous intestinal serositis, affecting 31 turtles $(33.33 \%)$. In addition, all turtles with fibrinous intestinal serositis also demonstrated fibrinous celomitis. Ca- 
Table 2. Systemic lesions and diseases of sea turtles $(n=93)$ stranded around the Canary Islands

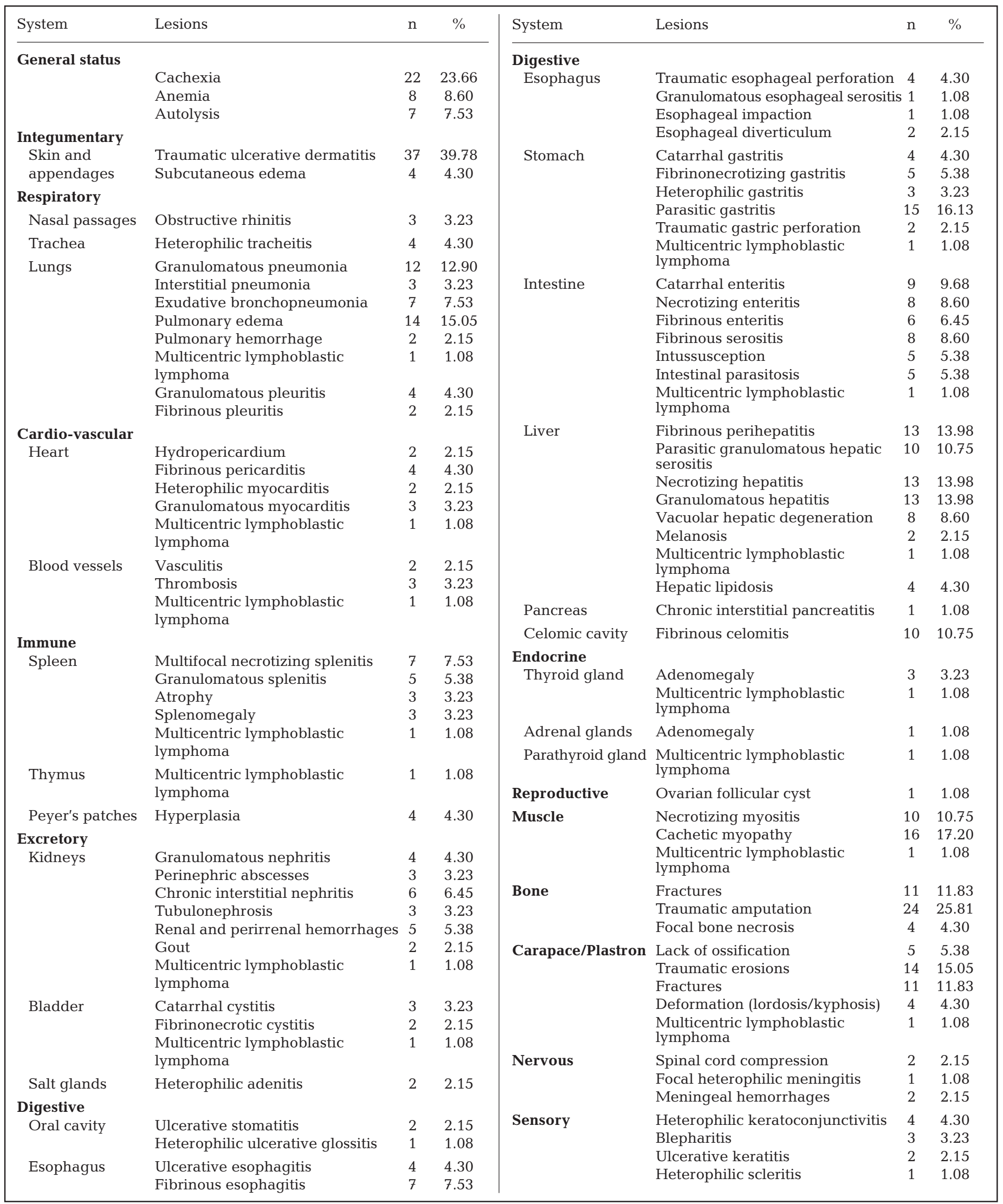




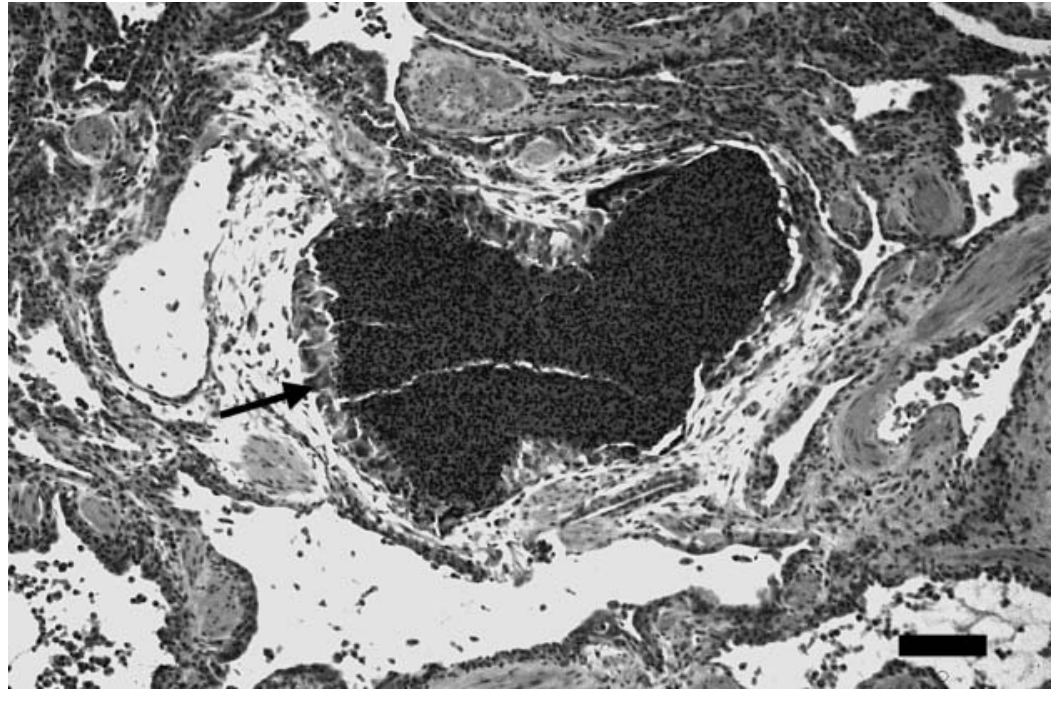

Fig. 2. Caretta caretta. Well-defined granuloma in pulmonary interstitium containing central necrotic eosinophilic debris mixed with heterophils. Note epithelioid cells (arrow) surrounding necrotic debris. Lesion was associated with Bacillus spp. infection. H\&E stain. Scale bar $=120 \mu \mathrm{m}$

tarrhal enteritis was characterized by a greyish exudate covering the intestinal mucosa and containing mucus and heterophils, in combination with a moderate number of heterophils in the lamina propria. Fibrinous enteritis was characterized by the presence of a yellowish exudate which was microscopically fibrillar and eosinophilic, and demonstrated large amounts of heterophils infiltrating the lamina propria. Necrotizing enteritis was characterized by edema, hemorrhage and necrosis of the intestinal mucosa, with necrotic inflammatory debris adhering to the mucosal surface. Fibrinous intestinal serositis was characterized by the presence of fibrin on the intestinal serosa, and large amounts of heterophils infiltrating the serosa. Fibrinous and necrotizing enteritis were associated with Bacillus spp., Escherichia coli, Pasteurella spp., Proteus spp., Serratia marcescens, Staphylococcus spp., Streptococcus spp., and Vibrio alginolyticus isolations. All cases of necrotizing enteritis were associated with intestinal intussusception caused by ingestion of monofilament fishing lines. Many of the cases of fibrinous intestinal serositis were also associated with multisystemic septicemic lesions.

Necrotizing and/or granulomatous hepatitis were the lesions most commonly observed in the liver (26/93 or $27.95 \%$ ). Necrotizing hepatitis was characterized by hepatocellular necrosis resulting in scattered foci, 1 to $3 \mathrm{~cm}$ in diameter, including an inflammatory reaction composed of mixed inflammatory cells. Granulomatous hepatitis was characterized by small, yellowish-whitish, granulomas scattered randomly throughout the liver. Microscopically, these granulomas were characterized by necrotic centers surrounded by macrophages and multinucleated giant cells (Fig. 5). Granulomatous hepatic serositis was observed in 10 turtles $(10.75 \%)$.

Cachetic myopathy was characterized by generalized atrophy of skeletal muscles, affecting 16 turtles (17.20\%), and with other underlying diseases. Localized necrotizing myositis was recorded in 10 turtles $(10.75 \%)$, and was attributed to entanglement in fishing nets or boat-strikes, and characterized by necrosis of the myofibers with infiltrating degenerated heterophils and bacteria, and an underlying layer of multinucleated giant cells.

Affections of the skeletal system were common. Traumatic amputation of 1 or 2 flippers was diagnosed in 24 turtles $(25.81 \%)$. These amputations were mainly related to entanglement in fishing nets. Multiple fractures of the humerus, ulna, radius or femur were diagnosed in 11 turtles (11.83\%). Antemortem and/or postmortem radiography confirmed the diagnosis in all cases.

Traumatic erosions and/or fractures of the carapace/ plastron were frequently observed (25/93 or $26.88 \%)$.

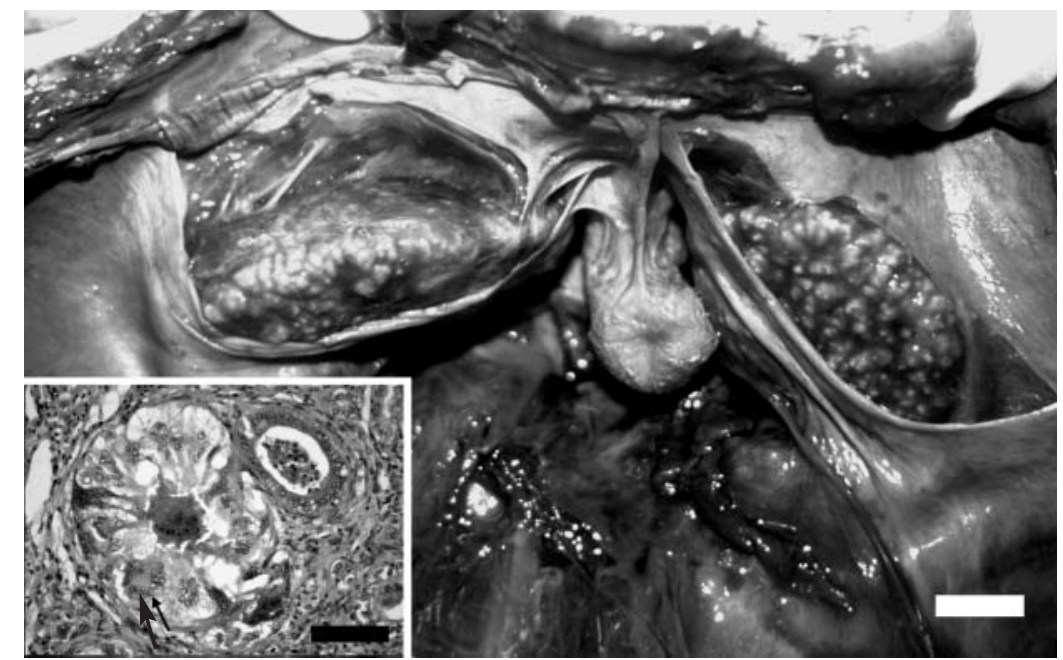

Fig. 3. Caretta caretta. Bilateral multiphocal granulomatous nephritis associated with Staphylococcus xylosus infection. Scale bar $=3 \mathrm{~cm}$. Inset: granuloma in renal interstitium containing central necrotic debris and surrounded by multinucleated giant cells (arrow). H\&E stain. Scale bar $=130 \mu \mathrm{m}$ 


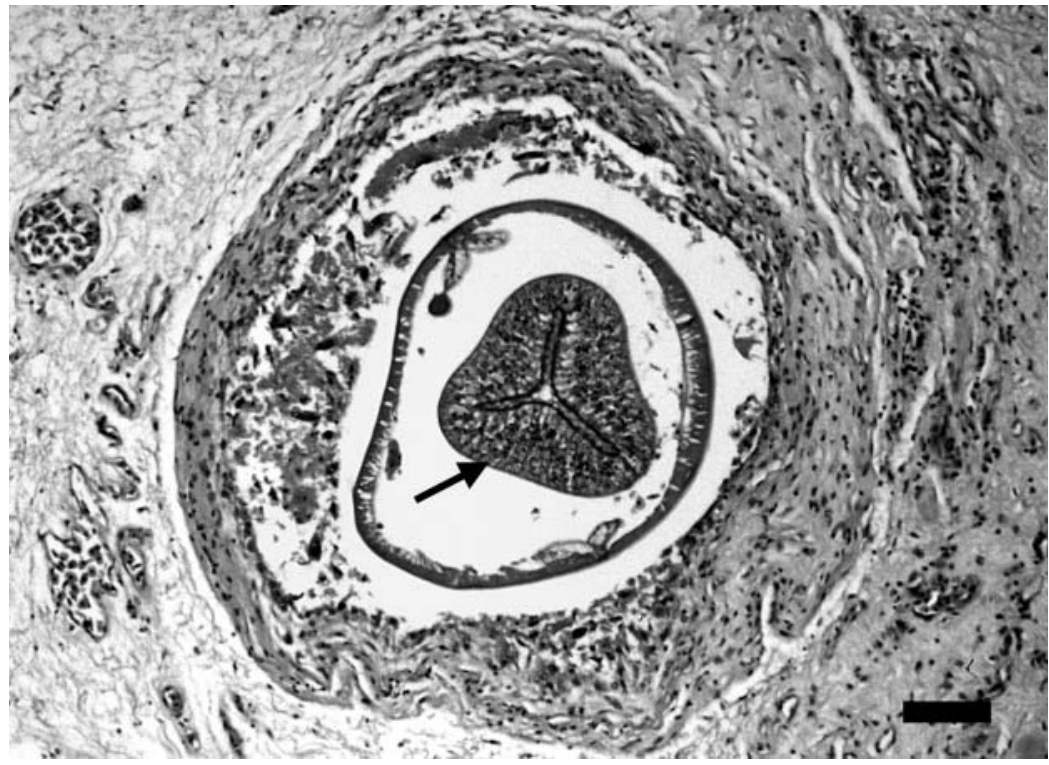

Fig. 4. Caretta caretta. Granulomatous inflammatory reaction caused by larval nematode in submucosa of the stomach, note characteristic esophagus of nema-tode (arrow). H\&E stain. Scale bar $=180 \mu \mathrm{m}$

mobacter spp. were isolated from these lesions (see Table 4).

A clinical history of crude oil ingestion was recorded in 2 turtles $(2.15 \%)$. Esophageal impaction with balls of crude oil, necrotizing gastroenteritis, necrotizing hepatitis, and tubulonephrosis were the lesions observed in these turtles.

\section{Bacterial and fungal diseases}

Several bacteria were isolated from lesions of the stranded turtles (Table 3). The prevalence of bacterial pathogens associated with different lesions is shown in Table 4. They included microorganisms which were considered to be potentially pathogenic and a number of opportunistic bacteria. Both Gram-negative and Gram-positive bacteria were commonly isolated. Staphylococcus was the genus most frequently isolated $(22.58 \%)$. Vibrio spp. was iso-

These lesions were mainly attributed to boat-strikes. Ulcerative shell disease was diagnosed in 1 loggerhead turtle and was characterized by the presence of ulcers involving the keratinous scutes of the carapace, mixed inflammatory cells and basophilic (H\&E) bacteria. Diseases of the nervous system were uncommon. Compression of the spinal cord due to traumatic injury or deformation of the spine was diagnosed in 2 turtles $(2.15 \%)$. Meningeal hemorrhages observed in 2 turtles were associated with traumatic lesions on the head due to boat-strikes.

Eye lesions included heterophilic keratoconjunctivitis, ulcerative keratitis and heterophilic scleritis, and affected 7 turtles $(7.53 \%)$. Heterophilic keratoconjunctivitis was characterized by the presence of large amounts of heterophils in the corneal stroma infiltrating the conjunctiva. Ulcerative keratitis was characterized by loss of epithelium of the cornea and the presence of large numbers of mixed inflammatory cells in the stroma. Heterophilic scleritis was characterized by edema and large numbers of heterophils in the sclera. Burkholderia cepacia, Pseudomonas spp., Staphylococcus spp., and Achro-

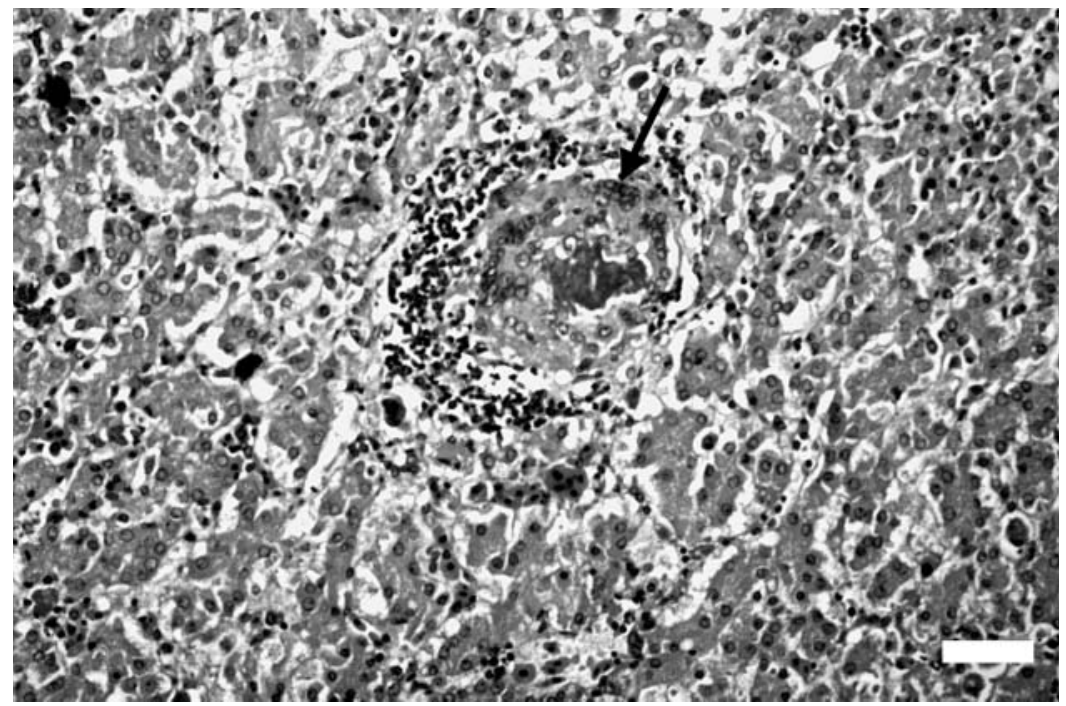

Fig. 5. Caretta caretta. Granulomatous hepatitis associated with Escherichia coli infection. Granuloma contains central eosinophilic debris and is surrounded by multinucleated giant cells (arrow) and lymphocytes. H\&E stain. Scale bar = $180 \mu \mathrm{m}$ 
Table 3. Bacteria isolated from stranded sea turtles Caretta caretta, Chelonia mydas and Dermochelys coriacea

\begin{tabular}{|llr|}
\hline Bacteria & Species affected (n) & \multicolumn{1}{c|}{$\%$} \\
\hline Achromobacter spp. & C. caretta (1) & 1.08 \\
Aerococcus viridans & C. caretta (1) & 1.08 \\
Aeromonas hydrophila & C. caretta (4) & 4.30 \\
Bacillus spp. & C. caretta (2) & 2.15 \\
Burkholderia cepacia & C. caretta (3) & 3.23 \\
Citrobacter spp. & C. caretta (4) & 4.30 \\
Escherichia coli & C. caretta (18) & 19.35 \\
Chryseobacterium & C. caretta (1) & 1.08 \\
meningosepticum & & \\
Pasteurella spp. & C. caretta (2) & 2.15 \\
Proteus spp. & C. caretta (8) & 8.60 \\
Pseudomonas spp. & C. caretta (5) & 5.38 \\
Serratia marcescens & C. caretta (1) & 1.08 \\
Staphylococcus spp. & C. caretta (20) & 22.58 \\
Streptococcus spp. & C. mydas (1) & \\
Vibrio alginolyticus & C. caretta (2) & 2.15 \\
& C. caretta (12) & 13.98 \\
& D. coriacea (1) & \\
\hline
\end{tabular}

\section{Parasitic diseases}

Larval nematodes found in the stomach, intestine and celomic cavity were identified as larvae from the Anisakidae family, based on the morphology of the esophagus (Rohde 1984). They occurred in 15 turtles
(16.13\%). Upon necropsy, migrating larvae were seen penetrating the gastric wall and passing through the gastric serosa into the liver and the celomic wall. Gross examination of some turtles did not reveal the presence of larvae. However, they were detected upon histological examination, in the lamina propria, submucosa and/or tunica muscular of the stomach and intestine. Microscopically, we observed a granulomatous inflammatory reaction in these cases. The granulomas containing the larvae had a central area of eosinophilic debris mixed with heterophils and macrophages, and multinucleated giant cells surrounding the necrotic debris. Encysted larvae in the liver capsule were observed in 10 turtles $(10.75 \%)$. Parasitic cysts consisted of several larvae surrounded by a wall of fibrous tissue.

Moderate numbers of nematodes morphologically identified as Sulcascaris sulcata (Allison et al. 1973) were observed in the small intestine of 3 loggerheads $(3.23 \%)$. Lesions associated with these parasites were not grossly detected.

\section{DISCUSSION}

Postmortem pathological surveys on sea turtles have been described by other authors (Glazebrook \& Campbell 1990a,b, Gordon et al. 1993). Rapid development of autolysis can impede the histological evaluation of the specimens. In our survey, only 7 turtles $(7.53 \%)$

Table 4. Prevalence (no. times isolated/no turtles examined) of bacterial pathogens associated with lesions in stranded turtles. Av: Aerococcus viridans; Ah: Aeromonas hydrophila; Bac: Bacillus spp.; Bc: Burkholderia cepacia; Cit: Citrobacter spp.; EC: E. coli; Cm: Chryseobacterium meningosepticum; Past: Pasteurella spp.; Prot: Proteus spp.; Psd: Pseudomonas spp.; Sm: Serratia marcescens; Stap: Staphylococcus spp.; Str: Streptococcus spp.; Va: Vibrio alginolyticus. Mixed cultures were detected. -: not detected

\begin{tabular}{|c|c|c|c|c|c|c|c|c|c|c|c|c|c|c|}
\hline Lesion & $A v$ & $A h$ & Bac & $B C$ & Cit & $E_{C}$ & $\mathrm{Cm}$ & Past & Prot & Psd & $S m$ & Stap & Str & $V a$ \\
\hline Ulcerative dermatitis & & $8 / 22$ & & & & & & & & & & $8 / 22$ & & $6 / 22$ \\
\hline Bronchopneumonia & - & - & - & $1 / 7$ & - & - & - & - & $1 / 7$ & - & - & $3 / 7$ & - & $2 / 7$ \\
\hline Granulomatous pneumonia & - & $2 / 8$ & $1 / 8$ & - & $1 / 8$ & - & - & $1 / 8$ & $1 / 8$ & $2 / 8$ & - & $1 / 8$ & $1 / 8$ & - \\
\hline Granulomatous pleuritis & - & $1 / 2$ & - & - & - & - & - & - & - & - & - & $1 / 2$ & - & - \\
\hline Pericarditis & - & - & - & - & - & - & - & - & - & - & - & $2 / 2$ & - & - \\
\hline Necrotizing splenitis & - & $1 / 7$ & - & - & - & $2 / 7$ & - & - & - & - & - & $3 / 7$ & $1 / 7$ & $2 / 7$ \\
\hline Granulomatous splenitis & - & - & $1 / 5$ & - & $1 / 5$ & - & - & - & - & - & - & $2 / 5$ & $1 / 5$ & - \\
\hline Granulomatous nephritis & - & - & - & - & $1 / 4$ & - & - & - & $1 / 4$ & - & - & $1 / 4$ & - & $1 / 4$ \\
\hline Perinephric abscesses & - & $1 / 3$ & - & - & - & $1 / 3$ & - & - & $1 / 3$ & - & - & $1 / 3$ & - & - \\
\hline Cystitis & - & - & - & - & $1 / 1$ & - & - & - & - & - & - & & - & - \\
\hline Ulcerative esophagitis & - & $1 / 4$ & - & - & $1 / 4$ & $1 / 4$ & - & - & - & - & - & $1 / 4$ & - & $1 / 4$ \\
\hline Fibrinous esophagitis & $1 / 7$ & - & - & - & - & $1 / 7$ & - & - & - & $2 / 7$ & - & $2 / 7$ & - & $2 / 7$ \\
\hline Gastritis & - & - & - & - & - & - & - & - & $1 / 3$ & - & - & $2 / 3$ & - & - \\
\hline Fibrinous enteritis & - & - & $2 / 6$ & - & - & $2 / 6$ & - & - & $2 / 6$ & - & - & $2 / 6$ & - & - \\
\hline Necrotizing enteritis & - & - & - & - & - & $3 / 8$ & - & - & $1 / 8$ & - & - & $1 / 8$ & $2 / 8$ & $1 / 8$ \\
\hline Fibrinous perihepatitis & - & - & - & - & - & $3 / 9$ & - & $1 / 9$ & $2 / 9$ & - & $1 / 9$ & $1 / 9$ & $1 / 9$ & - \\
\hline Necrotizing/Granulomatous hepatitis & - & $2 / 16$ & - & - & $2 / 16$ & $5 / 16$ & - & - & $3 / 16$ & - & - & $4 / 16$ & - & $2 / 16$ \\
\hline Myositis & - & $1 / 4$ & - & - & - & - & $1 / 4$ & - & - & - & - & $1 / 4$ & - & $2 / 4$ \\
\hline Keratoconjunctivitis & - & - & - & $2 / 3$ & - & - & - & - & - & $1 / 3$ & - & $1 / 3$ & - & - \\
\hline
\end{tabular}


were significantly autolyzed. However, in a previous study the percentage of autolysis among stranded sea turtles was high (12/29 or $41.3 \%$ ) (Orós et al. 1996). In recent years, better coordination between the local and regional institutions, the TWRC, and the Veterinary Faculty, ULPGC, has contributed to the more rapid submission of stranded sea turtles, even from other islands as Tenerife, Fuerteventura, Lanzarote and La Gomera.

In our study, traumatic skin lesions were the most common gross lesions (39.78\%), being associated with opportunistic Aeromonas hydrophila, Vibrio alginolyticus and Staphylococus spp. infections. These traumatic injuries were the sources from which pathogenic bacteria entered the tissues and the bloodstream, resulting in fatal septicemia. In a survey of the diseases of farmed sea turtles in northern Australia (Glazebrook \& Campbell 1990a), ulcerative dermatitis caused by trauma was observed in 66/102 turtles (63.5\%), being associated with opportunistic $V$. alginolyticus, $A$. hydrophila, Pseudomonas spp., and Chryseobacterium spp. infection. $V$. alginolyticus is regarded a normal inhabitant of seawater (Roberts 1978), while A. hydrophila has long been recognized as an opportunistic pathogen of reptiles (Reichenbach-Klinke \& Elkan 1965, Rosenthal \& Mader 1996).

Pulmonary lesions were considered important causes of mortality among sea turtles stranded in the Canary Islands. Several bacteria including Aeromonas hydrophila, Bacillus spp., Burkholderia cepacia, Citrobacter sp., Pasteurella spp., Proteus spp., Pseudomonas spp., Staphylococcus spp., Streptococcus spp., and Vibrio alginolyticus were associated with exudative bronchopneumonia and/or granulomatous pneumonia. Similar bacteria were isolated from bronchopneumonic lesions of turtles in Australia (Glazebrook \& Campbell 1990a,b). V. alginolyticus, A. hydrophila, and Chryseobacterium spp. have been repeatedly isolated from cases of ulcerative obstructive stomatitis and the rhinitis-pneumonia disease complex in hatchling and juvenile loggerhead and green turtles (Glazebrook et al. 1993). Granulomatous focal pneumonia has been frequently associated with Paecilomyces spp. infection in green turtles (Jacobson et al. 1979). The high prevalence of pulmonary lesions observed in sea turtles may indicate a predisposition of these animals to suffer from these pathologic processes. George (1997) considered the aspiration of seawater as one of the primary modes by which bacteria enter the respiratory system and cause clinical disease. In other cases the pulmonary lesions were secondary to traumatic injuries in the carapace (Fig. 6), as a consequence of the position of the lungs, these being dorsally attached to the carapace and the vertebral column (Wyneken 2001). The majority of the pneumonic lesions observed in our survey were unilateral, and it seems likely that the unilateral pneumonia in most cases was due to aspiration or penetrating shell trauma. Buoyancy problems observed in the turtles may indicate a pulmonary disease (Jacobson 1997). Turtle No. 69/1998 had been kept in an aquarium and we observed it adopting an asymmetrical floating pattern, with a lifting of the left side of the carapace. Necropsy revealed a severe granulomatous pneumonia restricted to the left lung (Fig. 2). Buoyancy disorders of sea turtles are not always associated with pulmonary lesions; they may also result from excessive gas in the gastrointestinal tract, such as that which collects during an obstruction (Campbell 1996, Jacobson 1997).

In our survey, the prevalence of cardiovascular lesions among stranded sea turtles was not high. All turtles with pericarditis and/or myocarditis had similar lesions in other organs. Thus, these lesions were an expression of a septicemic status, rather than of a specific cardiovascular disease. The most common cardiovascular pathology described in sea turtles is spirorchid fluke infection (Glazebrook et al. 1989, George 1997, Gordon et al. 1998). High prevalences of sea turtle spirorchidiasis have been reported in other surveys around the world (Glazebrook et al. 1989, Glazebrook \& Campbell 1990b, Gordon et al. 1998). Adult flukes have been found in the heart and major

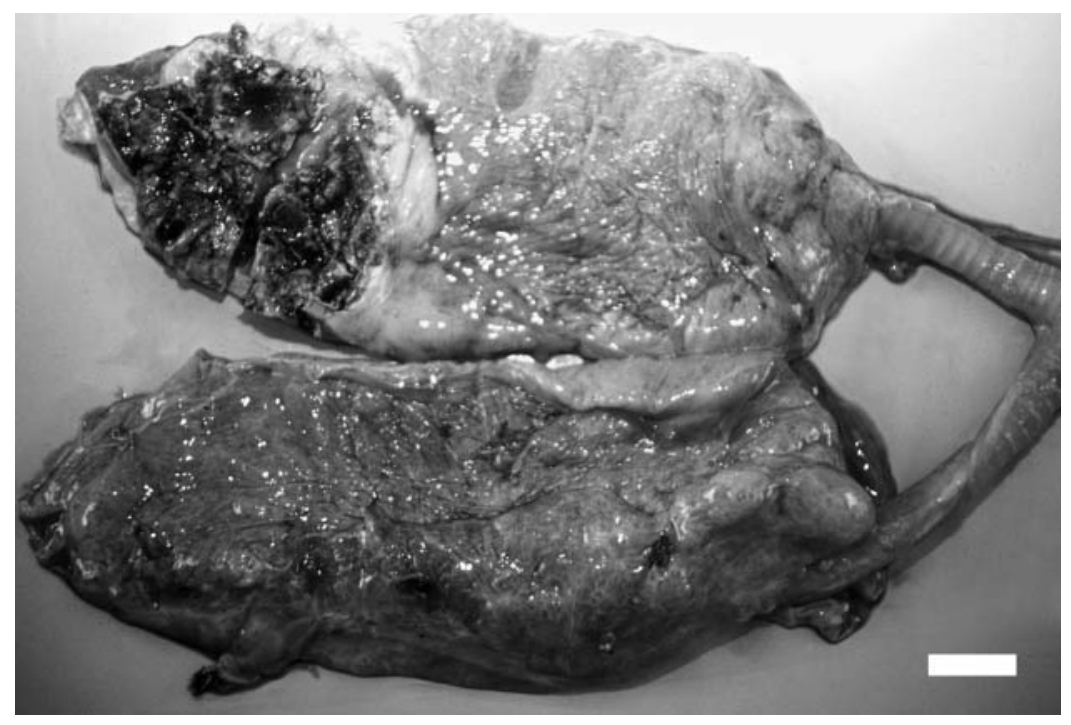

Fig. 6. Caretta caretta. Unilateral necrotizing pneumonia in turtle suffering from traumatic fracture of the carapace. The necrotic region correlated with the fracture site in the carapace. Scale bar $=3.5 \mathrm{~cm}$ 
blood vessels, causing lesions such as mural endocarditis, arteritis, thrombosis or aneurysms. Dissemination of the fluke eggs throughout the vascular system results in vasculitis and microgranulomas wherever they lodge (Wolke et al. 1982, Glazebrook et al. 1989, Gordon et al. 1998). However, none of the sea turtles in our study had intravascular adult flukes or trematode eggs in their tissues. All loggerhead and green turtles in our survey were juvenile and subadult specimens, whereas other studies in which spirorchidiasis was reported included adult turtles. Different alimentary habits of the juvenile and subadult turtles on the coasts of the Canary Islands could also explain the absence of spirorchid fluke infection. Sea turtles might acquire the flukes by ingesting unknown cercaria-rich intermediate hosts. The life cycle of spirorchids in sea turtles is unknown, but is probably similar to that of freshwater turtles (Holliman \& Fisher 1968).

Several species of bacteria were associated with necrotizing and granulomatous splenitis (Table 4). Many of the lesions involving the spleen were an expression of a septicemic status, rather than a specific splenic disease. Histopathological and ultrastructural features of the multicentric lymphoblastic lymphoma observed in a juvenile loggerhead have been published, being the first report of a lymphoid neoplasm in a sea turtle (Orós et al. 2001).

Granulomatous nephritis and renal abscesses were associated with Aeromonas hydrophila, Citrobacter spp., Escherichia coli, Proteus spp., Vibrio alginolyticus, and Staphylococcus spp. infections. In 4 cases, the renal lesions were secondary to traumatic injuries in the caudal aspect of the carapace, and related to the anatomical location of the kidneys, which were retrocelomically and dorsally attached to the caudal carapace (Wyneken 2001). In 5 cases, the renal lesions were attributable to a septicemic status with multiorganic involvement. Turtle No. 449/1999 suffered from a severe bilateral multifocal granulomatous nephritis associated with Staphylococcus xylosus infection (Fig. 3). Other lesions observed in this turtle included multifocal granulomatous hepatitis, multifocal granulomatous splenitis, multifocal granulomatous pneumonia, fibrinous pericarditis and myocarditis, and arteritis, in all cases associated with $S$. xylosus. To the best of our knowledge, there are no other reports of $S$. xylosus infection in sea turtles. This microorganism has been associated with cutaneous lesions in broiler chickens (Scalan \& Hargis 1989), goats (Mahanta et al. 1997), sheep (Gourreau et al. 1994), cats (Igimi et al. 1994), and mice (Bradfield et al. 1993).

Salt excretion in sea turtles is performed by highly specialized, modified lachrymal glands, whose function was investigated by Schmidt-Nielsen (1959). In our survey, heterophilic adenitis was observed in the salt glands of 2 sea turtles. No microbiological isolation was attempted. Glazebrook \& Campbell (1990a) reported Pseudomonas spp. infections in the salt glands due to the removal of foreign material from the main excretory duct.

Diagnoses of parasitic gastritis in sea turtles caused by the larval migration of nematodes belonging to the Anisakidae family were given by Carr \& Main (1973) and Rodgers \& Burke (1982). Turtles act as paratenic hosts for third-stage larvae unable to complete their life cycle when confined to the tissues of an ectothermic species (Glazebrook \& Campbell 1990a). The migration of larvae from the lumen of the stomach to the celomic cavity results in ulceration of the gastric mucosa and granulomatous inflammatory reactions. Although parasitic gastritis was observed in 15 turtles $(16.13 \%)$ in our survey, this pathologic condition was not considered a direct cause of mortality in any of the turtles examined.

Necrotizing and/or granulomatous hepatitis were commonly observed (26/93 or $27.95 \%$ ), being associated with Aeromonas hydrophila, Citrobacter spp., Escherichia coli, Proteus spp., Staphylococcus spp., and Vibrio alginolyticus infections. These hepatic lesions were attributable to multisystemic septicemic status. Granulomatous hepatic serositis was the result of the migration of larval nematodes from the stomach and intestine.

Necrotizing myositis was observed in 10 turtles $(10.75 \%)$, being caused in the majority of cases by entanglement in fishing nets (Fig. 7) or boat-strikes. These lesions were similar to those described by George (1997). Calabuig (1998) reported that 56\% $(45 / 72)$ of the turtles submitted to the TWRC in 1998 had similar lesions due to entanglement. These lesions have been previously described by other investigators (Schroeder 1987, Teas 1994, George 1997).

Eye lesions included heterophilic keratoconjunctivitis, ulcerative keratitis, heterophilic scleritis, and heterophilic blepharitis. One of the turtles suffering from heterophilic blepharitis also had heterophilic stomatitis and obstructive rhinitis. Burkholderia cepacia and Achromobacter spp. can be found in aquatic species, and are regarded as opportunistic pathogens. B. сераcia has been isolated from healthy fishes (Lemaitre et al. 1996) and has also been detected in humans with necrotizing pneumonia (Saini et al. 1999). Achromobacter spp. belongs to the normal dermal microflora of teleosts (Horsley 1977) and has also been isolated from healthy white whales Delphinapterus leucas (Buck et al. 1989). However, it has also been associated with dermal lesions in fish (Antychowicz \& Rogulska 1985, Zheng et al. 1991). Histological examination of the ocular and periocular lesions did not reveal 


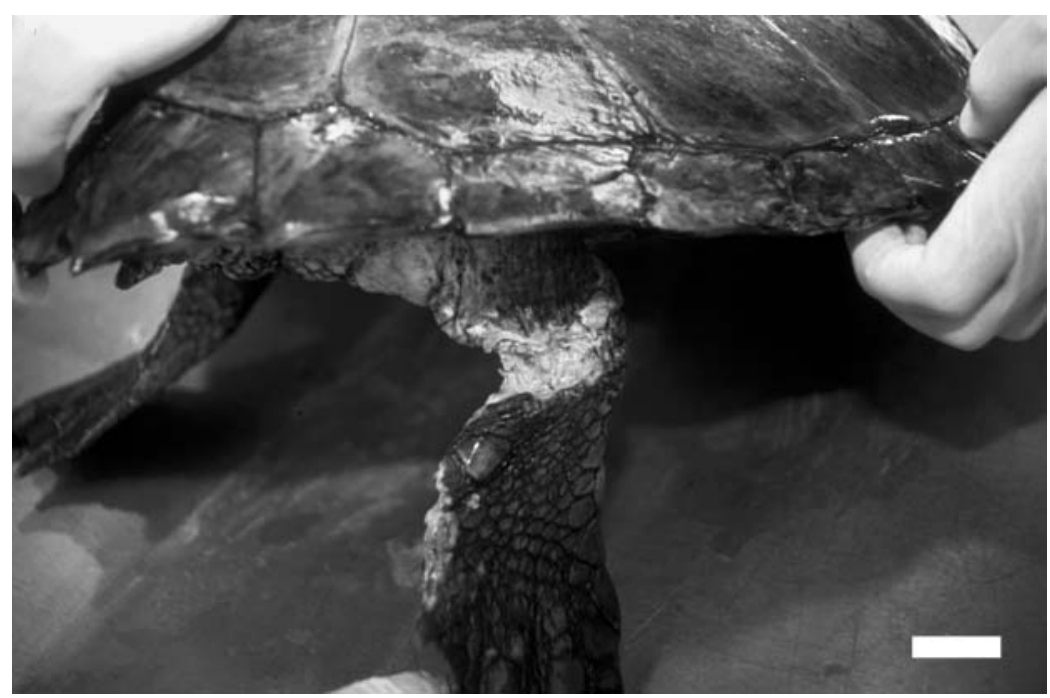

Fig. 7. Caretta caretta. Linear ulcerative dermatitis and myositis caused by entanglement in a fishing net. Scale bar $=2.7 \mathrm{~cm}$

intranuclear inclusion bodies indicative of a herpesvirus infection (Jacobson et al. 1986).

The absence of fibropapillomatosis in the sea turtles stranded arount the Canary Islands during this survey is remarkable, because fibropapillomatosis of sea turtles is a disease with global distribution. Renal fibromas were detected in 1 juvenile loggerhead stranded in 1994, but no cutaneous fibropapillomas were observed (Orós 1999). However, fibropapillomatosis affects several populations in epidemic proportions throughout the world, and many observations have been reported from Florida, Hawaii, Puerto Rico, Barbados, Virgin Islands, Panama, Colombia, Venezuela, Belize, Australia and Indonesia (Balazs 1991, Jacobson 1991, Adnyana et al. 1997). Its prevalence started to increase in the $1980 \mathrm{~s}$ at multiple sites, including Florida and Hawaii. The prevalence of fibropapillomatosis in sea turtle populations in Hawaii has been observed to be as high as $92 \%$ (Balazs 1991). In the Indian River Lagoon System of east central Florida, $57 \%$ of green turtles collected between 1985 and 1986 had fibropapillomatosis (Jacobson et al. 1989).

Taking into account the clinical reports, gross and microscopic lesions, and microbiological isolations, we attempted to establish the causes of mortality of the turtles examined in this survey (Table 5). Only 25 turtles $(26.88 \%)$ died of spontaneous diseases, including different types of pneumonia, hepatitis, meningitis, septicemic processes and neoplasia. However, 65 turtles $(69.89 \%)$ died from lesions associated with human activities such as boat-strike injuries (23.66\%), entanglement in derelict fishing nets $(24.73 \%)$, ingestion of hooks and monofilament lines $(19.35 \%)$, and crude oil ingestion $(2.15 \%)$.
Turtles with boat-strike injuries had severe fractures of the carapace/ plastron, and severe traumatic lesions, mainly penetrating the lungs and kidneys. Pulmonary lesions were typically unilateral, necrotizing pneumonia. Renal lesions were characterized mainly by perinephric abscesses. In addition, several cases of fibrinous celomitis and septicemia were also associated with these traumatic lesions. The international data show that vessel traffic is an important cause of sea turtle mortality. Between 1986 and 1993, about $9 \%$ of the living and dead stranded sea turtles in the US Gulf of Mexico and along the Atlantic coasts of Puerto Rico, and the US Virgin Islands, had boat-strike injuries (Schroeder 1987, Teas 1994). In the Canary Islands, boating along the coast is very popular among tourists and residents, but no studies on the consequences to the turtles have been published.

Net-entanglement is the most prevalent cause of sea turtle stranding in the Canary Islands, and frequently the turtles land with a part of the net still attached (Calabuig 1998). Entanglement in fishing nets results in severe ulcerative dermatitis, amputation of flippers and septicemic processes. A comparison of our survey and the data provided by the sea turtle stranding registry of the TWRC indicates that turtles with lesions induced by entanglement usually have a better prognosis for rehabilitation that those with traumatic lesions in the carapace or plastron. Affection of vital organs such as lungs and kidneys (because of their anatomical location, dorsally attached to the carapace), explain the generally poor prognosis for turtles with severe traumatic injuries to the carapace.

Ingestion of hooks and monofilament lines results in severe lesions in the gastrointestinal tract, resulting in the death of 18 turtles (19.35\%). Ingestion of hooks and monofilament lines resulted in ulcerative and fibrinous esophagitis, fibrinonecrotic gastritis, fibrinous and

Table 5. Estimated causes of mortality in the stranded sea turtles in this study

\begin{tabular}{|lrr|}
\hline Cause & $\mathrm{n}$ & $\%$ \\
\hline Entanglement & 23 & 24.73 \\
Trauma & 22 & 23.66 \\
Hooks + monofilament lines & 18 & 19.35 \\
Crude oil & 2 & 2.15 \\
Spontaneous diseases & 25 & 26.88 \\
Unknown & 3 & 3.23 \\
\hline
\end{tabular}


necrotizing enteritis, intestinal intussusception, severe celomitis, and septicemia. The estimated total catch of sea turtles in international waters to the north of the Canary Islands for 1983 to 1991 was 3000 turtles (López-Jurado \& González 1983, Blanco \& González 1992). Although many of the turtles are released by the fisherman, it is estimated that approximately 15 to $50 \%$ die due to the severe lesions induced by the fishing hooks (Lizana \& Barbadillo 1997).

Crude oil ingestion was considered as the cause of death in 2 turtles $(2.15 \%)$. In contrast to the usual high tolerance of sea turtles to physical damage, they are sensitive to crude oil. In laboratory studies using juvenile loggerhead sea turtles, almost all their major physiological systems were adversely affected by short exposure to crude oil (Lutcavage et al. 1995). On a yearly basis, about $1 \%$ of strandings identified by the US sea turtle stranding network were associated with crude oil exposure, with highest rates on South Florida (3\%) and Texas (3 to $6.3 \%$ ) beaches (Teas 1994).

This survey contributes to the information on the diseases and causes of mortality among sea turtles stranded in the Canary Islands. Research on the possible adverse health effects of exposure to persistent environmental contaminants, pesticides and heavy metals in the Canary Islands is currently under way.

Acknowledgements. The authors would like to thank P. Castro and J. L. Gallardo, Department of Morphology, University of Las Palmas de Gran Canaria, for technical assistance. We are grateful to members of Consejería de Medio Ambiente, Cabildo Insular de Gran Canaria, for providing us the turtles. We thank B. Acosta, Unit of Infectious Diseases (ULPGC), and A. Ruiz and J. M. Molina, Unit of Parasitic Diseases, for their collaboration in the microbiological and parasitological studies respectively. This study was partially supported by National Project I + D REN2000-1753 MAR, and the Consejería de Política Territorial y Medio Ambiente del Gobierno de Canarias.

\section{LITERATURE CITED}

Adnyana W, Ladds PW, Blair D (1997) Observations of fibropapillomatosis in green turtles (Chelonia mydas) in Indonesia. Aust Vet J 75:737-742

Allison VF, Webster RW Jr, Ubelaker JE, Riddle JM (1973) Redescription of Porrocaecum sulcatum (Rudolphi, 1819) from the sea turtle Chelonia mydas. Trans Am Microsc Soc 92:291-297

Antychowicz J, Rogulska A (1985) Preliminary investigations on the bacterial flora of the skin and erythrodermatitis ulcers of carp. Bull Vet Inst Pulawy 28-29:42-46

Balazs GH (1991) Current status of fibropapillomas in the Hawaiian green turtle, Chelonia mydas. NOAA Tech Memo NMFS SWFC-156:47-57

Bancroft JD, Stevens A (1996) Theory and practice of histological techniques, 4th edn. Churchill Livingstone, New York

Barbadillo LJ, Lacomba JI, Pérez-Mellado V, Sancho V, LópezJurado LF (1999) Anfibios y reptiles de la Península Ibérica,
Baleares y Canarias. Geoplaneta Editorial, Barcelona

Blanco JC, González JL (1992) Libro rojo de los vertebrados españoles. Colección Técnica ICONA, Ministerio de Agricultura, Pesca y Alimentación, Madrid

Boch J, Supperer R (1982) Generalidades. In: Boch J, Supperer R (eds) Parasitología en medicina veterinaria. Hemisferio Sur SA, Buenos Aires, p 1-47

Bradfield JF, Wagner JE, Boivin GP, Steffen EK, Russell RJ (1993) Epizootic fatal dermatitis in athymic nude mice due to Staphylococcus xylosus. Lab Anim Sci 43:111-113

Buck JD, Shepard LL, Bubucis PM, Spotte S, McClave K, Cook RA (1989) Microbiological characteristics of white whale (Delphinapterus leucas) from capture through extended captivity. Can J Fish Aquat Sci 46:1914-1921

Calabuig P (1998) Recuperación de tortugas marinas accidentadas en las Islas Canarias. Memoria de actividades realizadas en el Centro de Rehabilitación de Fauna Silvestre de Tafira. Ediciones del Cabildo de Gran Canaria, Las Palmas de Gran Canaria, p 35

Campbell TW (1996) Sea turtle rehabilitation. In: Mader DR (ed) Reptile medicine and surgery. WB Saunders, Philadelphia, PA, 427-436

Carr AF, Main AR (1973) Turtle farming project in Northern Australia. Report on an inquiry into ecological implications of a turtle farming project. Union Offset Pty, Canberra

Chaloupka MY, Musick JA (1997) Age, growth, and population dynamics. In: Lutz PL, Musick JA (eds) The biology of sea turtles, CRC Press, Boca Raton, FL, p 233-276

Duguy $R$, Morinière $P$, Le Milinaire C (1998) Facteurs de mortalité observés chez les tortues marines dans le golfe de Gascogne. Oceanol Acta 21:383-388

Frick MG (1996) A guide for the identification of stranded dead turtles: the Eastern United States and the Gulf of Mexico. Spec Publ Savannah Sci Mus 4: 22

George RH (1997) Health problems and diseases of sea turtles. In: Lutz PL, Musick JA (eds) The biology of sea turtles. CRC Press, Boca Raton, FL, p 363-386

Glazebrook JS, Campbell RSF (1990a) A survey of the diseases of marine turtles in northern Australia I. Farmed turtles. Dis Aquat Org 9:83-95

Glazebrook JS, Campbell RSF (1990b) A survey of the diseases of marine turtles in northern Australia. II. Oceanarium-reared and wild turtles. Dis Aquat Org 9:97-104

Glazebrook JS, Campbell RSF, Blair D (1989) Studies on cardiovascular fluke (Digenea: Spirorchiidae) infections in sea turtles from the Great Barrier Reef, Queensland, Australia. J Comp Pathol 101:231-250

Glazebrook JS, Campbell RSF, Thomas AT (1993) Studies on an ulcerative stomatitis-obstructive rhinitis-pneumonia disease complex in hatchling and juvenile sea turtles Chelonia mydas and Caretta caretta. Dis Aquat Org 16:133-147

Gordon AN, Kelly WR, Cribb TH (1998) Lesions caused by cardiovascular flukes (Digenea: Spirorchidae) in stranded green turtles (Chelonia mydas). Vet Pathol 35:21-30

Gordon AN, Kelly WR, Lester JG (1993) Epizootic mortality of free-living green turtles, Chelonia mydas, due to coccidiosis. J Wildl Dis 29:490-494

Gourreau JM, Colardelle C, Filleton R, Fontaine JJ (1994) Dermatitis due to Staphylococcus xylosus in sheep. Point Vet 26:271-274

Greiner EC, Forrester DJ, Jacobson ER (1980) Helminths of mariculture-reared green turtles (Chelonia mydas) from Grand Cayman, British West Indies. Proc Helminthol Soc Wash 47:142-144

Holliman RB, Fisher JE (1968) Life cycle and pathology of Spirorchis scripta Stunkard, 1923 (Digenea: Spirorchiidae) in Chrysemys picta picta. J Parasitol 54:310-318 
Horsley RW (1977) A review of the bacterial flora of teleosts and elasmobranchs, including methods for its analysis. J Fish Biol 10:529-553

Igimi $\mathrm{S}$, Atobe $\mathrm{H}$, Tohya $\mathrm{Y}$, Inoue A, Takahashi E, Konishi S (1994) Characterization of the most frequently encountered Staphylococcus sp. in cats. Vet Microbiol 39: 255-260

IUCN/SSC (International Union for Conservation of Nature and Natural Resources/Species Survival Commission) (1995) A global strategy for the conservation of marine turtles. IUCN, Balmar, Arlington, VA

IUCN/SSC (International Union for Conservation of Nature and Natural Resources/Species Survival Commission) (2002) 2002 IUCN red list of threatened species. IUCN, Balmar, Arlington, VA, available at www.redlist.org

Jacobson ER (1991) An update on green turtle fibropapilloma. NOAA Tech Memo NMFS SWFC-156:59-71

Jacobson ER (1997) Buoyancy problems in sea turtles: causes and diagnosis. In: Proc Annu Meet Am Assoc Zoo Vets. Houston, TX, p 10

Jacobson ER, Gaskin JM, Shields RP, White RH (1979) Mycotic pneumonia in mariculture-reared green sea turtles. J Am Vet Med Assoc 175:929-932

Jacobson ER, Gaskin JM, Roelke M, Greiner EC, Allen J (1986) Conjunctivitis, tracheitis, and pneumonia associated with herpes-virus infection in green sea turtles. J Am Vet Med Assoc 189:1020-1023

Jacobson ER, Mansell JL, Sundberg JP, Hajjar L, Reichmann ME, Ehrhart LM, Walsh M, Murru F (1989) Cutaneous fibropapillomas of green turtles (Chelonia mydas). J Comp Pathol 101:39-52

Lemaitre C, Orange N, Saglio P, Saint N, Gagnon J, Molle G (1996) Characterization and ion channel activities of novel antibacterial proteins from the skin mucosa of carp (Cyprinus carpio). Eur J Biochem 240:143-149

Lizana M, Barbadillo LJ (1997) Legislación, protección y estado de conservación de los anfibios y reptiles españoles. In: Pleguezuelos JM (ed) Distribución y biogeografía de los anfibios y reptiles en España y Portugal. Universidad de Granada Editorial, Granada, p 477-516

López-Jurado LF, González S (1983) Las tortugas en Canarias. Aguayro 147:29-31

Lutcavage M, Lutz PL, Bossart G, Hudson D (1995) Physiologic and clinicopathologic effects of crude oil on loggerhead sea turtles. Arch Environ Contam Toxicol 28: 417-422

Mahanta PN, Thungchamo K, Dutta GN, Devriese LA (1997) Identification and characterization of staphylococci isolated from cutaneous lesions of goats. J Vet Med Ser B 44:309-311

Mateo JA, Andreu AC, López-Jurado LF (1997) Las tortugas marinas de la Península Ibérica, Baleares, Azores, Madeira y Canarias: introducción. In: Pleguezuelos JM (ed) Distribución y biogeografía de los anfibios y reptiles en España y Portugal. Universidad de Granada Editorial, Granada, p 433-434

Orós J (1999) Aplicación de nuevas técnicas en el diagnóstico de la fibropapilomatosis en tortugas marinas. Bol Asoc Herp Esp 10:43-46

Orós J, Torrent A (2001) Manual de necropsia de tortugas marinas. Ediciones del Cabildo de Gran Canaria, Las Palmas de Gran Canaria

Orós J, Déniz S, Rodríguez JL, Rodríguez F, Molina JM (1996)

Editorial responsibility: Peernel Zwart,

Utrecht, The Netherlands
Hallazgos anatomopatológicos y microbiológicos en reptiles mantenidos en cautividad y tortugas marinas de vida libre. Rev Esp Herp 10:117-125

Orós J, Torrent A, Espinosa de los Monteros A, Calabuig P, Déniz S, Tucker S, Jacobson ER (2001) Multicentric lymphoblastic lymphoma in a loggerhead sea turtle (Caretta caretta). Vet Pathol 38:464-467

Pritchard PCH (1997) Evolution, phylogeny, and current status. In: Lutz PL, Musick JA (eds) The biology of sea turtles. CRC Press, Boca Raton, FL, p 1-28

Raidal SR, Ohara M, Hobbs RP, Prince RI (1998) Gram-negative bacterial infections and cardiovascular parasitism in green sea turtles (Chelonia mydas). Aust Vet J 76:415-417

Reichenbach-Klinke H, Elkan E (1965) The principal diseases of lower vertebrates. Diseases of reptiles. Academic Press, London

Roberts RJ (1978) Fish pathology. Bailliere Tidall, London

Rodgers LJ, Burke JB (1982) Gastric ulceration associated with larval nematodes. Anisakis Type I in pen-reared green turtles from the Torres Strait. J Wildl Dis 18:41-46

Rohde K (1984) Diseases caused by metazoans: helminths. In: Kinne O (ed) Diseases of marine animals, Vol IV. Biologische Anstalt Helgoland, Hamburg, p 193-320

Rosenthal KL, Mader DR (1996) Microbiology. In: Mader DR (ed) Reptile medicine and surgery. WB Saunders, Philadelphia, PA, p 117-125

Saini LS, Galsworthy SB, John MA, Valvano MA (1999) Intracellular survival of Burkholderia cepacia complex isolates in the presence of macrophage cell activation. Microbiology 145:3465-3475

Scalan CM, Hargis BM (1989) A bacteriologic study of scabby-hip lesions from broiler chickens in Texas. J Vet Diagn Investig 1:170-173

Schmidt-Nielsen K (1959) Salt glands. Sci Am 200:109-116

Schroeder BA (1987) Annual Report of the sea turtle stranding and salvage network Atlantic and Gulf coasts of the United States January-December 1986 (Coastal Resource Division contribution CRD-87/88-12). National Oceanic and Atmospheric Administration, National Marine Fisheries Service, Miami, FL

Smith GM, Coates CW (1938) Fibro-epithelial growths of the skin in large marine turtles, Chelonia mydas (Linnaeus). Zoology 23:93-98

Teas WG (1994) Annual Report of the Sea Turtle Stranding and Salvage Network Atlantic and Gulf coasts of the United States January-December 1993. (Miami Laboratory contribution MIA-94/95-12). National Oceanic and Atmospheric Administration, National Marine Fisheries Service, Miami, FL

Wanson JC, Drochman P (1988) Epoxy technique inclusion for electron microscopy. Cell Biol 38:130-133

Wolke RE, George A (1981) Sea turtle necropsy manual. NOAA Tech Memo NMFS SEFC-24:20

Wolke RE, Brooks DR, George A (1982) Spirorchidiasis in loggerhead sea turtles (Caretta caretta): pathology. J Wildl Dis 18:175-185

Work TM, Balazs GH (1998) Causes of sea turtle mortality in Hawaii. NOAA Tech Memo NMFS SEFSC-415:291-292

Wyneken J (2001) The anatomy of sea turtles. NOAA Tech Memo NMFS SEFSC-470:172

Zheng T, Jian X, Aubert J, Aubert M (1991) Studies on opportunistic pathogens and bacterial flora in the Pagrosomus major-rearing water environment. Rev Int Oceanogr Méd 101-104:78-82

Submitted: May 7, 2003; Accepted: May 15, 2004

Proofs received from author(s): December 8, 2004 